\title{
Role of Auxin on Growth, Yield and Quality of Tomato - A Review
}

\author{
Kartik Pramanik* and Priyadarshani P. Mohapatra \\ Department of Horticulture, M. S. Swaminathan School of Agriculture, CUTM, India \\ *Corresponding author
}

\section{A B S T R A C T}

\section{Keywords}

Growth regulator,

IAA, NAA, 4-CPA, 2,

4-D, TSS,

Parthenocarpic

Article Info

Accepted:

15 September 2017

Available Online:

10 November 2017
A growth regulator, plant growth regulator, or PGR, is a natural or synthetic chemical that is sprayed or otherwise applied to a seed or plant in order to alter its characteristics. They are sometimes referred to as plant hormones. Plant growth regulators function as chemical messengers for intercellular communication. In tomato, different growth regulators play a pivotal role in germination, root development, branching, flower initiation, fruiting, lycopene development, synchronization and early maturation, parthenocarpic fruit development, ripening, TSS, acidity, seed production etcetera. To boost the tomato production in India these versatile resources greatly help the professionals and researchers. By keeping the importance of growth regulator in tomato production this review paper is scripted.

\section{Introduction}

Tomato (Lycopersicon esculentum Mill.) is one of the most widely cultivated crops in the world. It is an important source of vitamins and an important cash crop for small-holders and medium-scale commercial farmers. It is one of the most popular salad vegetables and is taken with great relish. Food value of tomato is very rich because of higher contents of vitamins $\mathrm{A}, \mathrm{B}$ and $\mathrm{C}$ including calcium and carotene (Bose and Som, 1990). Uddain et al., (2009), Rashid (1983), Davies and Hobes (1981) reported that tomato adds flavor to the foods and it is also rich in medicinal value. Tomato has a significant role inhuman nutrition because of its rich source of lycopene, minerals and $\beta$-carotene which are anti-oxidants and promote good health.
Tomato contains organic acids like citric, malic and acetic acids which is found in fresh tomato fruit, promotes gastric secretion, acts as a blood purifier and works as intestinal antiseptic (Pruthi, 1993).

Among vegetables, tomato occupies 4th position in area and 2nd position in production in India. The present area and production of tomato in the country 8.82 lakh ha and 187.35 lakh tones respectively in 2010 (NHB, 2014). While in Andhra Pradesh, it is cultivated about an area of 1.67 lakh ha with a production of 33 lakh tones (NHB, 2014).

Although tomato plants can grow under a wide range of climatic conditions, they are 
extremely sensitive to hot and wet growing conditions (Ahmad, 2002). Increasing temperature, viral diseases and salinity are the major limiting factors in sustaining and increasing tomato productivity (Fekadu and Dandena, 2006). There are generally various constraints resulting in low production of vegetables including tomato which includes poor soil fertility, water scarcity, poor cultivation skills, attack of pest and disease, poor availability of inputs and harsh climate (Baliyan and Kgathi, 2009). Lack of adoptive cultivars and poor fruit setting of existing varieties especially during the hot/dry season where the demand for tomato is very high is one challenge farmers are facing in tomato production even though there is potential land for cultivation. Breeding for heat tolerance in tomato crop has been difficult due to many factors like moderate heritability inheritance being complex or the cultivars becoming lower in yield (George et al., 1984). Tomato fruit set is very sensitive to environmental conditions, in particular, to too low or high temperatures that affect pollen development and anther dehiscence. Fruit set depends on the successful completion of pollination and fertilization (Gillaspyet al., 1993). Tomato requires day temperature of $21-28^{\circ} \mathrm{C}$ and moderately cool night temperature of 15 $20^{\circ} \mathrm{C}$ for proper fruit setting. High temperature (both day and night), humidity, rainfall and light intensity are the limiting factors of tomato production (Abdulla and Verkerk, 1968). High day and night temperature above $32^{\circ} \mathrm{C}$ and $21^{\circ} \mathrm{C}$, respectively, was reported as limiting factor to fruit-set due to an impaired complex of physiological process in the pistil, which results in floral or fruit abscission (Picken, 1984). High temperatures reduces fruit set, fruit production and yield in tomato (Peet et al., 1997). For good fruit set and better yield, pollination, germination of pollen grains, pollen tubes growth, fertilization and fruit initiation must take place successfully (Kinet and Peet, 1997). Gelmesa et al., (2010) explained that high relative humidity of the air, low light intensity and extreme low and high temperature, and improper mineral nutrition seems to be involved in the control of those phenomena and result in low fruit set and quality. High day and night temperature above $32^{\circ} \mathrm{C}$ and $21^{\circ} \mathrm{C}$, respectively, was reported as limiting factor to fruit-set due to an impaired complex of physiological process in the pistil, which results in floral or fruit abscission (Picken, 1984).

Plant growth regulators (PGRs) are used extensively in horticulture to enhance plant growth and improve yield by increasing fruit number, fruit set and size (Batlang, 2008 and Serrani et al., 2007a). Use of growth regulators had improved the production of tomato including other vegetables in respect of better growth and quality (Saha, 2009). Fruit set in tomato can be increased by applying plant growth regulators to compensate the deficiency of natural growth substances required for its development (Singh and Choudhury, 1966). Induction of artificial parthenocarpy through application of PGRs enables fertilization-independent fruit development that can reduce yield fluctuation in crops like tomato, pepper and likes (Heuvelink and Korner, 2001). Plant growth regulators such as auxins and gibberellins are known to affect parthenocarpy (Matlob and Kelly, 1975), fruit setting (Rappaport, 1957) and fruit size (Osborne and Went, 1953); therefore synthesized auxins and gibberellins are often used for promotion of fruit set in some fruit vegetable production including tomatoes (Kuo and Tsai, 1984) and yields can increase dramatically to four times Abdulla (1978).

As more native auxin is transported down the stem to the roots, the overall development of the roots is stimulated. The longer and branched root can uptake more nutrients from 
the soil which are accumulated to the plant sink and increase the yield (Wang et al., 2005). If the source of IAA is removed, such as by trimming the tips of stems, the roots are less stimulated accordingly.

Rahul et al., (2005) investigated that plant growth was not affected significantly by any treatment and interaction between different doses of PGRs (control, 25 or 75 ppm IAA, and 25 or 75 ppm NAA) and micronutrient (control, 2500 ppm Multiplex or 2000 ppm Humaur) mixtures.

On the other hand, most report indicated that synthetic auxin like 2, 4-D has herbicidal or ephinastic effect (Pandolfini et al., 2002) which lead to flower bud abscission, poor fruit set, fruit defects and puffiness beyond certain concentrations. This is due to herbicidal effect of 2, 4-D at higher concentrations hastened maturity of the plants so that they complete their life cycle in a short period of time. Serrani et al., (2007) indicated that high doses of 2, 4-D resulted in some malformations in tomato.

In fact the use of growth regulators had improved the production of tomato including other vegetable in respect of better growth and quality which ultimately led to generate interest between the scientists and farmers for commercial application of growth regulators. Keeping in view, this review paper is enlisted to summarize the importance of growth regulators in tomato cultivation.

\section{Role of auxin}

The most important Auxin produced by plants is indole-3-acetic acid (IAA). It plays important roles in a number of plant activities, including phototropism, gravitropism, apical dominance, fruit development, abscission androot initiation. A couple of synthetic auxins are 2, 4-Dand 2, 4, 5-T.

\section{Role of auxin on flowering and fruiting of tomato}

Synthesized auxin are often used for promotion of fruit set in some fruit and vegetable production including tomatoes (Gemici et al., 2006; Khan et al., 2006; Serrani et al., 2007; Batlang, 2008). IAA is required for fruit growth and development and delays fruit senescence and plays also a minor role in the initiation of flowering and development of reproductive organs (Asahira et al., 1967). Patel et al., 2012 revealed that application NAA increases the fruit diameter in tomato. Verma et al., 2014 revealed that fruit set in tomato was successfully improved by application of NAA. Leopold (1964) observed that with the increase in concentration of auxin there was a comparable increase in percentage of flower cluster. Mukharji and Roy (1966) found that application of IAA had protected the flower and premature fruit drop and increased length of size fruit in tomato plant. Singh and Upadhayaya (1967) studied the effect of IAA and NAA on tomato and reported that the regulators induce parthenocarpic fruit.

Khaled et el. (2015) reported that days required for $50 \%$ flowering, days required for fruit setting, fruit cluster plant $^{-1}$ and fruit plant $^{-1}$ were significant influenced by the combined application of IAA in BARI tomato 7, Manik and Ratan varieties of tomato. Singh et al., (2003) stated that the beta naphthoxyacetic acid (BNOA) have positive effect on seed germination and fruit set, and earlier flowering in tomato. Baliyan et al., 2013 revealed that application of 4-CPA in summer tomato increases the number of tomato fruit set. The application of 4-CPA hormone has significant effect on the tomato fruit set (Ozguven et al., 1997; Sasaki et al., 2005). Mehta and Mathai (1976) observed that spraying of tomato plant with NAA 0.2 ppm ant $0.1 \mathrm{ppm}$ gave significantly increased 
fruit set, and number of days taken to fruit setting was significantly lesser to control. Kaushik et al., (1978) showed that alpha NAA at 1,10 , or $100 \mathrm{mg} / \mathrm{I}$ increased fruit set per plant at lowest concentration, the highest concentration markedly reduced fruit number when sprayed on tomato plants at the 2 leaf stage. Sagar et al., (1978) noted that NAA 20 ppm as a whole plant spray at flowering stage gave significantly increased fruit number in tomato. It was also noted that significantly higher yield in tomato by foliar application of NAA 10 and $20 \mathrm{ppm}$ at time of first flowering. Younis and Tigani (1978) reported that 2 sprays of NAA $10 \mathrm{ppm}$ at time of flowering stage gave significantly increased flower and fruit set in tomato. Gupta et al., (2001) recorded minimum day for fruit setting in plant was 42 DAT, observed significantly with the treatment of 25 ppm NAA alone with Humaur (P3M2).

Rodrigues et al., (2001) studied that tomato spraying with 10 ppm NAA followed by pollination on initial trusses resulted in the highest number of fruits (45.63) and seed yield (0.58 g per plant). Jagdish et al., (2002) confirmed that spraying PCPA at $50 \mathrm{ppm}$ to the flower clusters significantly improved the fruit set per cluster compared with the control, but increasing the concentration to 100 and $150 \mathrm{ppm}$ had no significant effect on fruit set. NAA spray had no effect on fruit set per cluster when compared with the control. Mukherji and Roy (1966) and Howlett (1941) reported that fruit set in tomato wassuccessfully improved by application of NAA and IAA.

Similarly, sprays of NAA or $\beta$-NAA at the time of flowering resulted in reduced preharvest fruit drop and increased the number of fruits per plant (Alam and Khan, 2002). Synthetic auxin 4-CPA (4-chloro phenoxy acetic acid) reduced pre-harvest fruit drop with increased number of fruits per plant and yield (Sasaki et al., 2005). Application of 4$\mathrm{CPA}$ is more effective during anthesis period than one week after anthesis (Poliquit et al., 2007).Gelmesa et al., 2012 reported that application of 2, 4-D at 5 and 10 ppm resulted in reduced plant growth and hastened early flowering and fruiting with concentrate pick harvest. Gemici et al., (2006) that suggested high concentrations of 2, 4-D at $10 \mathrm{ppm}$ produced fewer fruits in tomato. Pandolfini et al., 2002 indicated that synthetic auxin like 2, 4-D has herbicidal or ephinastic effect which lead to flower bud abscission, poor fruit set, fruit defects and puffiness beyond certain concentrations. Gelmesa et al., 2010 indicated that, 2, 4-D beyond certain concentration leads to flower bud abscission and fruit drop due to its herbicidal effect. Gimici et al., (2006) who suggested that high concentrations of $2,4-\mathrm{D}$ at $10 \mathrm{mg} \mathrm{l}^{-1}$ produced fewer fruits than with 4-CPA. Gelmesa et al., 2012 revealed that the interaction effect of 2 , 4-D and GA3 indicated that fruit length was maximum for both levels of 5 and $10 \mathrm{mg} \mathrm{l}^{-1} 2$, 4-D with $10 \mathrm{mg} \mathrm{l}^{-1}$ of GA3 but significantly reduced when the concentration of GA3 increased. Serrani et al., (2007a) reported that, tomato fruits induced by 2, 4-D had thicker pericarp than pollinated fruits throughout its development, and more in response to 2, 4-D than GA3.

\section{Role of auxin on cell division and cell elongation of tomato}

IAA stimulates cell elongation by stimulating wall-loosening factors, such as elastins, to loosen cell walls and the effect is stronger if gibberellins are also present (Bunger-Kibler and Bangerth, 1983). IAA also stimulates cell division if cytokinins are present (Zhao, 2008). IAA induces the formation and organization of phloem and xylem. When the plant is wounded, the IAA may induce the cell differentiation and regeneration of the vascular tissues (Ulmasov et al., 1999). 
Role of auxin on root development and apical dominance of tomato

IAA promotes root initiation and induces both growth of pre-existing roots and adventitious root formation, i.e., branching of the roots (Varga and Bruinsma, 1976). As more native auxin is transported down the stem to the roots, the overall development of the roots is stimulated. The longer and branched root can uptake more nutrients from the soil which are accumulated to the plant sink and increase the yield (Wang et al., 2005). If the source of IAA is removed, such as by trimming the tips of stems, the roots are less stimulated accordingly. IAA induces shoot apical dominance and the axillary buds are inhibited by IAA (Woodward and Bartel, 2005). IAA promotes root initiation and induces both growth of pre-existing roots and adventitious root formation, i.e., branching of the roots (Varga and Bruinsma, 1976). Alfono and Alonso (1981) found that the root proliferation occurred in tomato (cv. Manalucie) shoot segments cultured on Murashige and Skoog media with combination of $0.01,0.1,0.5$ and $1.0 \mathrm{mg} /$ NAA and 0.01, 0.1, and $0.5 \mathrm{mg} / \mathrm{l} \mathrm{BA}$. Higher concentrations of NAA ( 2 and $4 \mathrm{mg} / \mathrm{I})$ and BA (1, 2 and $4 \mathrm{mg} / \mathrm{I})$ inhibited rooting. Singh (1999) observed that the IBA and NAA (250$500 \mathrm{ppm})$ promoted rooting in tomatoes. Higher net returns were observed in the treatment with IBA at $500 \mathrm{ppm}$ alone or in combination with (250-500 ppm). Taylor and Scheuring (2004) reported that the frequency of lateral root initiation in tomato seedling roots is increased over eightfold in response to $1.6 \mathrm{M}$-naphthalenacetic acid (NAA).

\section{Role of auxin on growth of tomato}

Patel et al., 2012 revealed that application NAA increases the plant height and number of branches in tomato. Abdel Rahman (2008) assessed changes in growth, endogenous levels of hormones, and ethylene evolution and cellulite and pectolytic enzyme activities of cherry tomato fruits from anthesis through ripening. After anthesis, growth of cherry tomato fruit follows a three - dimensional and sigmoid growth pattern which consists of cell division, cell enlargement and mature green. Pink and red stages. Cytokinins and auxins were abundant and reached their peak during early development (cell division). Ali et al., (2012) reported that IAA produces highest number of branches per plant in tomato. Chhonkar and Singh (1959) reported that high concentration of IAA reduced plant height. Khaled et al., (2015) reported that Plant height, number of leaves and number of branches were significant influenced by the combined application of IAA in BARI tomato 7, Manik and Ratan varieties of tomato. Singh et al., (2005) saw that plant growth and number of branches of tomato positively affected by IAA and NAA. Singh and Upadhyay (1967) observed that NAA 10ppm increased the height and higher doses significantly reduced the height. Mehrotra et al., (1971) reported that NAA $25 \mathrm{ppm}$ had little effects on plant height but there was no effect on number of branches when tomato seedling where treated for 30 minutes before transplanting. It was also reported that quality of fruit was improved with the application of NAA $25 \mathrm{ppm}$. Patil and Mahajan (1971) noted that higher concentration of NAA 0.4 ppm induced more height in tomato seedling when seedling roots wee dipped for 24 hours prior to transplanting, while the average diameter of branches number and leaves were not affected.

Singh et al., (1981) reported that height of the main stem of the plant varied due to the plant growth regulators treatment. IAA and NAA resulted in production of taller plants, maximum number of branches and yield $\mathrm{q} / \mathrm{ha}$ in tomato. Gupta et al., (2001) recorded significantly maximum plant height at 75 
DAT and maximum number of branches at 60 with 75 ppm NAA alone with 2000 ppm NAA as compared to control. Kishan Swaroop et al., (2001) recorded maximum number of primary branches in the treatment NAA $25 \mathrm{ppm}$. While the lowest number of primary branches was recorded in the treatment boron $50 \mathrm{ppm}$. Number of primary branches was not influenced by the growth regulatory substances. Singh et al., (2011) revealed application NAA have positive effect on vegetative growth of three tomato cultivars viz., NUN-1560 (V1), NUN-964 (V2) and NUN-963 (V3). Application of IAA as foliar sprays or to the by moderately high rainfall during Kharif (April growing media of tomato plants had a stimulatory effect September) season and low temperature $\left(15^{\circ}-20^{\circ} \mathrm{C}\right)$ in on plant growth and development (Hathout et al., 1993). Chhonkarand Ghufran (1968) reported that plant height decreased with the increased concentration of NAA concentration.

Hathout et al., (1993) found that application of $10 \mathrm{ppm}$ IAA as foliar sprays or to the growing media of tomato plants had a stimulatory effect on plant growth, development and fruit which was accompanied by increases in endogenous auxin, gibberellins and cytokinin contents. However, IAA at $80 \mathrm{ppm}$ had an inhibitory effect on plant growth and development, which was accompanied by increase in the level and activity of indigenous inhibitors and by low levels of auxms, cytokines and gibberellins. Karim et al., (2015) observed that 4-chlorophenoxy acetic acid (4-CPA) had a significant influence on growth of tomato var. BARI Hybrid Tomato- 8 . The synthetic auxin 2, 4-D mimics the function of natural auxins which control "a multitude of plant growth and development processes" (Hess, 1993). Patel et al., (2012) revealed that application 2, 4-D increases the plant height and number of branches in tomato. Anwar (2010) indicated that application of 2, 4-D at
$5 \mathrm{mg} \mathrm{l}^{1}$ significantly improved growth attributes of tomato plant but those attributes decreased beyond this concentration.

\section{Role of auxin on yield of tomato}

Patel et al., 2012 revealed that application NAA increases the fruit diameter and yield in tomato. Ali et al., (2012) reported that IAA produces highest number of flower per plant and yield in tomato. Application of NAA increases the yield in tomato due to enhanced plant growth and faster rate of plant development by the action of NAA in cell elongation and there by increased cell enlargement, cell division and differentiation which in turn result into increase in number of flowers, fruit set, size and weight of fruit as reported by Rodrigues et al., (2001), Kishan et al., (2001), Rai et al., (2002), Nibhavanti et al., (2004), Singh and Sant (2005) and Bokade (2006). Chhonkar and Singh (1959) recorded increasing yield of tomato by seedling treatment with growth substances. They reported that high concentration of IAA increases yield through increased flower induction and fruit set. Singh and Upadhayaya (1967) studied the effect of IAA and NAA on tomato and reported that the regulators increased the fruit set, size and yield of fruit. The chemicals could be applied on seeds, roots whole plants or flowers, but foliar application was very effective for increasing the size of fruit and the yield. Kaushik et al., (1974) reported that $10 \mathrm{ppm}$ of IAA increased the number and weight of fruits per plant significantly. Khaled et al., (2015) reported that weight tomato-1, yield plant-1, yield plot1 and yield hectare-1 were significant influenced by the combined application of IAA in BARI tomato 7, Manik and Ratan varieties of tomato. Singh et al., (2005) saw that yield of tomato positively affected by IAA and NAA. Gupta et al., (2003) found highest yield with application of IAA + Multiplex micronutrient mixture at the 
maturity stage during. Baliyan et al., (2013) revealed that application of 4-CPA in summer tomato increases the number of tomato fruit set which helps in increasing in fruit yield. Alam and Khan (2002) revealed that reduced pre-harvest fruit drop with increased number of fruits per plant and yield was observed due to Naphthalene Acetic Acid (NAA) or b-NAA spray. Habbasha et al., (1999) found that application of IAA increased fruit set percentage and total fruit yield compared to control. Singh and Upadhyay (1967) observed that NAA $10 \mathrm{ppm}$ as soil and foliar application give increased yield in tomato but NAA 20 ppm significantly reduced yield. It is also observed that the largest fruit size was found with $75 \mathrm{ppm}$ NAA along with multiplex at maturity stage of tomato and gave the maximum yield (Gupta et al., 2003). Patil and Mahajan (1971) noted that NAA 0.1 ppm resulted more weight of fruits per plant and NAA $0.05 \mathrm{ppm}$ as seedling root dipping from 24hrs gave higher percent of yield in fruit and second picking. Perenz Zapata et al., (1980) found that tomato Cvs. Floral and Marglobe, treated with NAA at 25 and 35 ppm had large fruit size. Singh et al., (1981) reported that IAA and NAA resulted highest yield q/ha in tomato. Alam and Khan (2002) reported that spray of NAA at variable concentration significantly increased the fruits yield of tomato as compared to control. Gupta et al., (2003) reported that the application of $75 \mathrm{ppm}$ NAA along with multiplex resulted in largest fruit size at maturity stage of tomato and gave maximum yield. Singh et al., (2011) revealed application NAA have positive effect on yield of three tomato cultivars viz., NUN1560 (V1), NUN-964 (V2) and NUN-963 (V3). Arvind (2012) reported that combination of variety "NBH NO-1" and 15 ppm NAA was found best in respect increasing productivity of tomato crop. Karim et al., (2015) observed that 4-chlorophenoxy acetic acid (4-CPA) had a significant influence on yield of tomato var. BARI
Hybrid Tomato-8. Gemici et al., (2006) indicated increased fruit size and setting in tomato due to application of 2, 4dichlorophenoxy acetic acid (2, 4-D), 4chlorophenoxy acetic acid (4-CPA) and $\beta$ naphthoxya cetic acid ( $\beta$-NAA). The synthetic auxin 2, 4-D mimics the function of natural auxins which control "a multitude of plant growth and development processes" (Hess, 1993). Patel et al., (2012) revealed that application 2, 4-D increases the fruit diameter and yield in tomato. Gelmesa et al., (2010) reported that application of 2, 4-D at or lower concentration of $5 \mathrm{mg} \mathrm{l}^{-1}$ improves the fruit yield and quality of tomato variety Fetan. Anwar (2010) indicated that application of 2, 4-D at $5 \mathrm{mg} \mathrm{l}^{-1}$ significantly improved fruit yield of tomato plant but those attributes decreased beyond this concentration. Pudir and Yadav (2001) that indicated improvement in tomato fruit yield at low concentration (5 $\mathrm{mg}^{-1}$ ) of 2, 4-D. Khan et al., (2006) stated that 2, 4-D increases longer fruits with bigger size in tomato which could be due to stimulation of parthenocarpic fruit growth that resulted in increased fruit weight. Gemici et al., (2006) also reported that 2, 4-D resulted in increased tomato fruit size, fresh and dry weight when used at recommended concentration.

\section{Role of auxin on quality of tomato}

Patel et al., (2012) revealed that application NAA increases the acidity and TSS in tomato. Perez and Ramirez (1980) carried out an experiment with the application of IAA at 25 and $35 \mathrm{ppm}$ on tomato. They found increased fruit size quality with minimum seeds. Gupta et al., (2003) found the largest fruit size, most attractive ripe fruit color highest dry matter and ash content with application of IAA + Multiplex micronutrient mixture at the maturity stage during. NAA application in tomato increased total soluble solid percentage significantly (Pudir and Yadav, 
2001). Habbasha et al., (1999) found that application of IAA reduces the percentage of puffy and parthanocarpic fruit and compared to control. Mehrotra et al., (1971) reported that quality of fruit was improved with the application of NAA $25 \mathrm{ppm}$. Petronk and Loban (1975) obtained quality of tomato seed by treating the seed with IAA at $100 \mathrm{mg} / \mathrm{kg}$ or NAA at $50 \mathrm{mg} / \mathrm{kg}$ before sowing. Pandita et al., (1978) found higher fruit acidity in tomato plant treated with NAA 100 ppm as foliar spray at appearances of first flowering. The highest vitamin ${ }^{\prime} \mathrm{C}^{\mathrm{ee}}$ content was in fruit from the plant treated with NAA $50 \mathrm{ppm}$.

The beneficial effect of NAA at $100 \mathrm{ppm}$ on fruit T.S.S. was also observed. Alam and Khan (2002) reported that spray of NAA at variable concentration significantly increased the nutrient contents of fruits. Rai et al., (2002) reported that maximum chlorophyll content and acidity were obtained with NAA at $75 \mathrm{ppm}$ along with Humaur at $2000 \mathrm{ppm}$. NAA at 75 ppm along with Multiplex at 2500 ppm gave the highest sugar content. Singh et al., (2011) revealed application NAA have positive effect on quality of three tomato cultivars viz., NUN-1560 (V1), NUN-964 (V2) and NUN-963 (V3). Thakur et al., (1996) indicated that the ascorbic acid content increased with higher concentrations of 2, 4$\mathrm{D}$ and Para-chlorophenoxy acetic acid.

From this review it can be clearly inferred that application of $10 \mathrm{ppm}$ IAA, $50 \mathrm{ppm}$ PCPA, 20 ppm NAA or 5ppm 2, 4-D as foliar sprays had a stimulatory effect on plant growth, flowering and, fruit setting, yield and quality of fruit which was accompanied by increases in endogenous auxin, gibberellins and cytokinin contents in tomato plant. So applying of both natural and synthetic auxin helps farmer in cultivating tomato in adverse climatic condition which can give good fruit yield by increasing vegetative and reproductive growth and reducing the flower and fruit drop.

\section{References}

Abdel-rahman. 2008. Patterns of hormones, respiration and ripening enzymes during development, maturation and ripening of cherry tomato fruit. Physiologia Plantarum., 39 (2): 115-118.

Abdulla K.S. 1978. Effect of CCC on the formation and abortion of flower in the first inflorescence of tomato (Lycopersicon esculentuln Mill).Annals of Botany. 42: 617-625.

Abdullah A.A. and Verker K. 1968. Growth, flowering and fruit-set of the tomato at higher temperature. Neth. J. Agric. Sci. 16:71-76.

Ahmad S. 2002. Genetics of fruit set and related traits in tomato under hot-humid conditions. Ph.D. Thesis. BSMRAU. pp. $44-180$.

Alam S.M. and Khan M.A. 2002. Fruit yield of tomato as affected by NAA spray. Asian J. Plant Sci., 1 (1):24.

Alfonso A. and AlonsoR.M. 1981. Effect of NAA and BA on root formation in tomato shoots cultured in vitro. Ciencias de la Agri., 10:41-45.

Ali M., Sharmin A., Saki S., M-ul-Hasan A. I., and Moniruzzaman M. 2012. Effect of plant growth regulators on growth and yield of tomato (Lycopersicon esculentum Mill.) varieties. International Journal of Sustainable Agricultural Technology. 8 (1): 1-6.

Anwar W., Aziz T., Naveed F. and Sahi S.T. 2010. Short Communication. Foliar applied 2, 4-dichlorophenoxy acetic acid improved tomato growth and yield. Soil Environ. 29(1): 77- 81.

Arvind J. 2012. Effect of plant growth regulators on different varieties of tomato (Lycopersicon esculentum Mill.), M. Sc. Thesis, R.A.K College of Agriculture Sehore 466001 (M.P.)

Asahira T., Takeda Y., Nishio T., Hirabayashi 
M. and Tsukamoto, Y. (1967).Studies on fruit development in tomato. I. Ovule development and content of diffusible auxin- and gibberellin-induced parthenocarpic tomato fruits in relation to their development. Memoirs of the Research Institute for Food Science, Kyoto University 28: pp. 47-74.

Baliyan S. P., Madhava Rao K. S., Baliyan P. S. and Mahabile M. 2013. The effects of 4-Chlorophenoxyacetic acid plant growth regulator on the fruit set, yield and economic benefit of growing tomatoes in high temperatures. International Journal of Agricultural Science and Research (IJASR): ISSN 2250-0057, Vol. 3, Issue 2, 29-36

Baliyan S.P. and Kghati D.L. 2009. Production and marketing problems in small scale horticultural farming in Botswana. Acta Hort. (ISHS) 831: 3140.

Batlang U. (2008). Benzyladenine plus gibberellins (GA4+7) increase fruit size and yield in greenhouse-grown hot pepper (Capsicum annuum L.). Journal of Biological Science 8(3): 659-662.

Bokade N. 2006. Effect of growth regulators on growth and yield of summer tomato. J. Maharashtra Agric. Univ., 31(1): 6465.

Bose T. K. and Som M. G. 1990. Vegetable crops in India. Naya Prakash, Calcutta, India. pp. 687-691.

Bunger-Kibler S. and Bangerth F. (1983). Relationship between cell number, cell size and fruit size of seeded fruits of tomato (Lycopersicon esculentum Mill.) and those induced parthenocarpically by the application of plant growth regulators. Plant Growth Regulation 1: pp. 143-154.

Chhonkar V. S. and Singh S. N. 1959. Effect of alpha naphthalene acetic acid on growth, quality and yield of tomato. India. J. Hort., 16: pp. 236- 242.
Chhonkar V.S. and Ghufran M.H. 1968. Effect of starters and NAA on growth and yield of Lycopersicon esculentum.. IndIan J. Hort., 25: 72-75.

Davies G.M. and Hobes G. 1981.The constituent of tomato fruit the influence of environment nutrition and genotypes. Critical Rev. Food Sci. \& Nutri. 15: 205-280.

Fekadu M. and Dandena G. 2006. Review of the status of vegetable crops production and marketing in Ethiopia. Uganda $J$. Agric. Sci., 12(2): 26-30.

Gelmesa D., Abebie B. and Lemma D. 2010. Effects of Gibberellic acid and 2, 4dichlorophenoxyacetic acid spray on fruit yield and quality of tomato (Lycopersicon esculentum Mill.). Journal of Plant Breeding and Crop Science, Vol. 2(10). pp. 316-324,

Gelmesa D., Abebie B. and Lemma D. 2012. Regulation of tomato (Lycopersicon esculentum Mill.) fruit setting and earliness by gibberellic acid and 2, 4dichlorophenoxy acetic acid application. African Journal of Biotechnology, Vol. 11(51), pp. 11200-11206

Gemici M., Türkyilmaz B. and Tan K. 2006. Effect of 2, 4-D and 4-CPA on yield and quality of the tomato, Lycopersicon esculentum Mill. JFS, 29: 24-32.

George W.L., Scott J.W. and Splittstoesser W.E. 1984. Parthenocarpy in tomato. Hortic. Rev., 6: 65-84

Gillasp G., Ben-David H. and Gruissem W. 1993. Fruits: a developmental perspective. The Plant Cel, 15, 14391451.

Gupta P. K., Gupta A. K. and Reddy S. 2003.Response of plant growth regulators and micronutrient mixtures on fruit size, color and yield of tomato (Lycopersicon esculentum Mill.). Ann. Agric. Res., 24 (1): pp. 100-103.

Gupta P.K., Gupta N.K. and Reddy S. 2001. Efficiency fo plant growth regulators 
and micronutrient mixture on growth and shelf life of tomato (Lycopersicon esculentum Mill.) fruit. India J. Agric. Biocem., 14 (1\&2): 63-65.

Habbasha K.M., Gomea H.M., Glasy A.M. and Mohamed S.S. 1999. Response of tomato plantto foliar spray with some growth regulators under late summer conditions. Egyptium J. Horti., 26(1) 35-36.

Hathout T.A., Sheteawi S.A. and Khallal S.M. 1993. I. Effect of mode of application of some growth regulators on the physiology of tomato plants. II. Effect of IAA on endogenous hormonal contents. Egyptian J. Physiol. Sci., 17(1): 45-62.

Hess F.D. 1993. Herbicide effects on plant structure, physiology and biochemistry. In Pesticide interactions in crop production: Beneficial and deleterious effects, ed. Altman, J. Boca Raton: CRC Press.

Heuvelin E. and Korner O (2001). Parthenocarpic Fruit Growth Reduces Yield Fluctuation and Blossom-end Rot in. Sweet Pepper. Ann. Bot., 88: 69-74.

Howlett P.S. 1941. Effect of indoleacetic acid upon tomato fruit set and development. Proc. Amer. Soc. Hort. Sci., 39: 217-28.

Jagdish Singh, Singh K. P. and Kalloo G. 2002. Effect of some plant growth regulators on fruit set and development under cold climatic conditions in tomato (Lycopersicon esculentum Mill.). Progressive Horticulture, 34: (2) 211214.

Karim Md. R., Nahar Most. Altaf-Un and Sahariar Md. S. 2015. Improvement of summer tomato (Lycopersicon esculentum Mill.) production using 4chlorophenoxy acetic acid. Journal of Bioscience and Agriculture Research; 04 (02): 86- 91

Kaushik H.P., Sharma J.K. and Singh I. 1978. Effect of alpha naphthalene acetic acid, gibberellic acid, Kinetin and morphactin on yield of tomato. Plant Sci., 6:51-53.

Kaushik M. P., Shanna J.K and Singh I. 1974. Effect of alpha naphthalene acetic acid, gibberellic acid, kinetin and morphactin on yield of tomato. Plant Sci, 6: 51-53.

Khaled A. M., Sikder S., Islam M. R., Hasan M. A. and Bahadur M. M. 2015. Growth Yield and Yield Attributes of Tomato (Lycopersiconesculentum Mill.) as Influenced by Indole Acetic Acid.J. Environ. Sci. \& Natural Resources.8 (1): pp.139-145.

Khan M.M.A., Gautam A.C., Mohammad F., Siddiqui M.H., Naeem M., Khan M.N. 2006. Effect of gibberellic acid spray on performance of tomato. Turk. J. Biol., 30: 11-16.

Kinet J. M. and Peet M.M. 1997. Tomato. In H.C Wien (ed.). The Physiology of Vegetable Crops. CAB International, pp. 207-248.

Kishan S.T.V., Sharma R.S. and Attri B.L. 2001. Effect of alphanapthalene acetic acid and 2-4-D on growth quality and yield of tomato cultivars. Madras Agri. J., 30 (10-12):723-726.

Kuo C.G. and Tsai C.T. 1984. Alternation by high temperature of auxin and gibberellins concentrations in the floral buds, flowers and young fruit of tomato. Hortscience, 19: 870 - 872.

Leonard M., Kinet K.M., Bodson M. and Bernier G. 1983. Enhanced Inflorescence development in tomato by growth substance treatments in relation to $14 \mathrm{C}$ assimilate distribution. Physiologia plant arun. 57 (1): 85-89.

Matlob A.N. and Kelly W. C. 1975. Growth regulator activity and parthenocarpic fruit production in snake melon and cucumber grown at high temperature. Journal of American Society of Horticulture Science, 100: 406- 409.

Mehrotra O. N., Grag R.C. and Singh I. 1971. Growth, fruiting and quality of tomato 
(Lycopercon esculentum Mill.) as influenced by growth regulators. Prog. Hort., 2 (1): 57-64.

Mehta A.C. and Mathai P.J. 1976. Effect of growth regulators on summer tomato. Haryana. Prog. Hort., 4 (3-4): 167-176.

Mukherji S.K. and Roy B.K. 1966. Reducing fruit drop in West Bengal. World Crops, 18(3): 34 .

NHB, 2014

(http://nhb.gov.in/PDFViwer.aspx?enc= 3ZOO8K5CzcdC/Yq6HcdIxC0U1kZZe nFuNVXacDLxz28=)

Nibhavanti B.K., Bhalekar M.N., Gupta N.S. and Deshpande A.N. 2004. Effect of growth regulators on growth and yield of tomato. J. Maharashtra Agric.Univ. 31(1):64-65.

Osborne D.J. and Went F.W. (1953) Climatic factors influencing parthenocarpy and normal fruit set in tomatoes. Botanical Gazette, Vol114, No 3, 312-322

Ozguven A.I., Paksay M. and Abak K. 1997. The effects of 4-CPA in tomato growing in green house on the fruit set, quality and amount of 4-CPA residue in fruits. Proceeding of the 8th International Horticultural Symposium on Plant Bio regulation in Fruit Production. Acta Horticulture, 463: 243-248.

Pandita M.L., Arora S.K. and Singh K. 1978. Effect of plant growth regulator on the chemical composition of tomato (Lycopersicon esculentum Mill.) C.V.H.S.-101. Haryana J. Hort. Sci., 5(1-2): 65-72.

Pandolfini T., Rotino G.L., Camerini S., Defez R., Spena A. 2002. Optimization of transgene action at the posttranscriptional level: High quality parthenocarpic fruits in industrial tomatoes. BMC Biol., 2: 1-11.

Patel J. S., Sitapara H.H. and Patel K.A. 2012.Influence of plant growth regulators on growth, yield and quality of tomato and brinjal, Internat. J.
Forestry \& Crop Improv., 3 (2) : 116118.

Patil A.V. and Mahajan P.H. 1971. Effect of plant growth regulator on growth, yield and eariness in tomato. Res. $J$. Mahatma Phule Agril. Univ., 2 (1):5660.

Peet M.M., Willits D. H. and Gardne R. 1997. Response of ovule development and post-pollen production processes in male -sterile tomatoes to chronic, subacute high temperature stress. Journal of Experimental Botany, 48: 101-111.

Perez, Z. M. and Ramirez O. G. 1980.Effect of season and growth regulators on flowering, fruit-set and development of the tomato. Puerto Rico J. Agric., 64 (4): pp. 460-473.

Petronk, A.V. and Lovan T.I. 1975. Application of synthetic growth substance in green house tomato cultivation. Balovusakgo Univ., 2: 101105, Hort. Abst., 4(2) : 697.

Picken A.J.F. (1984). A Review of pollination and fruit set in the tomato (Lycopersicon esculentum Mill). Journal of Horticultural Science. 55: 113.

Poliquit R.D. and Diputadu M.T. 2007. Tomato fruit parthenocarpy and yield increase in response to chlorophenoxyacetic acid. Ann. Trop. Res., 29(1): 14-25.

Pruthi J. S. (1993). Major spices of India. Crop management and post harvest technology. Indian j. Agric. Res. New Delhi.

Pudir J.P.S. and Yadav P.K. 2001. Note on effect of GA3 NAA and 2, 4-D on growth, yield and quality of tomato var. Punjab Chuhara. Curr. Agric., 25: 137138.

Rahul Singh, Sant A. K. and Lal Singh. 2005. Effect of plant growth regulators and micro-nutrient mixtures on growth and 
yield of tomato (Lycopersicon esculentum Mill.). Bioved., 16: (1/2) 101-105.

Rai G.K., Singh J., Singh S. and Gupta A.K. 2002. Effect of plant growth regulators (IAA and NAA) and micronutrient mixtures (Humaur and Multiplex) on growth, yield and quality of tomato (Lycopersicon esculentum Mill.) Ann. Biol. (India), 18(1):13-17.

Rappaport L. 1957. Effect of gibberellins on growth, flowering and fruit setting of the Earlypark tomato, Lycopersicum esculentum. Plant Physio., 32, 440-444.

Rashid M.M. 1983. 1st Edn., Begum Shahla Rashid Publishers, Joydebpur, Gajipur, 86-87.

Rodrigues M.J., Warade S.D. and Patil S.D. 2001. Effect of growth regulators and truss sequence on hybrid seed yield of tomato hybrid. Adv. Plant Sci., 14(2):495-499.

Sagar V., Saini S.S. and Rattan R.S. 1978. Effect of plant growth regulators on yield and number of fruit in tomato (Lycopersion esculentum Mill.). Seeds and Farms, IV (1-2): 22-24.

Saha P. (2009). Effect of NAA and GA3 on yield and quality oftomato (Lycopersicon esculentum Mill). Environ. \& Ecol., 27(3):1048-1050.

Sasaki H., Yano T. and Yamasaki A. 2005. Reduction of high temperature inhibition in tomato fruit set by plant growth regulators. JARQ Japan International Research Centre for Agriculture, 39 (2): 135-138.

Serrani J.C., Fos M., Atare's A. and Garci'aMarti'nez J.L. 2007. Effect of gibberellin and auxin on parthenocarpic fruit growth induction in the cv MicroTom of tomato. J. Plant Growth Regul. 26: 211-221.

Serrani J.C., Fos M., Atare's A. and Garci'aMarti'nez J.L. 2007a. Effect of gibberellin and auxin on parthenocarpic fruit growth induction in the cv MicroTom of tomato. J. Plant Growth Regul. 26: 211-221.

Singh B. K., Singh A. K. and Rai V.K. 2011. Role of NAA on growth, yield and quality of tomato (Lycopersicon esculentum Mill.) cultivars. Environment and Ecology., 29: (3) 1091-1093.

Singh B., Singh N., Singh S. K. and Kumar S. 2003. Effects of phytohormones with different methods of application on the growth and yield of tomato (Lycopersicon esculentum Mill.). Prog. Agric., 3 (1/2): pp.33-35.

Singh D.K. 1999. Response of hybrid tomato to growth regulators. Indian J. Agric. Sic., 69 (7): 523-525.

Singh D.K. 1999. Response of hybrid tomato to growth regulators. Indian J. Agric. Sic., 69 (7): 523-525.

Singh J., Singh M.P., Rajput R.P. and Singh D.B. 1981. Effect of pre-sowing treatment with growth regulators on tomato. Food Farming and Agric., 14 (6): 7071.

Singh K. and Upadhayaya S. K. 1967. A comparative study of soil and foliar application of IAA and NAA on several response of tomato. Horticulturist. 2: pp.3-9.

Singh R. and Sant A.K. 2005. Effect of plant growth regulator's and micronutrient mixture on the growth and yield of tomato. Bioved, 16(1-2):101-105.

Singh R., Sant A. K. and Singh L. 2005. Effect of plant growth regulators and micro-nutrient mixture on growth and yield of tomato (Lycopersicon esculentum Mill.). Bioved, 16 (1-2): pp. 101-105

Singh S.N. and Choudhury B. 1966. Effect of various plant growth regulators and their method of application on quality of tomato fruits. Indian J Hort; 23:156157. 
Taylor B.H. and Scheuring C.F. 2004. A molecular market for lateral root intiation: The RSI-1 gene of tomato (Lycopersicon esculentum Mill) is activated in early lateral root primordial. Molecular and General Genetics MGG., 243 (2): 148-157.

Thakur B.R., Singh R.K., Nelson P. 1996. Quality attributes of processed tomato products: A review. Food Res. Int., 12: 375-401.

Uddain J., Akhter Hossain K.M, Mostafa M.G. and Rahman M.J. 2009. Effect of Different Plant Growth Regulators on Growth and Yield of Tomato, International Journal of Sustainable Agriculture, 1 (3): 58-63

Ulmasov T., Hagen G. and Guilfoyle T.J. 1999.Dimerization and DNA binding of auxin response factors. The Plant Journal, 19: pp. 309-319.

Varga A. and Bruinsma J. 1976. Roles of seeds and auxins in tomato fruit growth. Zeitschrift fur Pflanzenphysiologie, 80: pp. 95-104.

Verma P. S., Meena M. L. and Meena S. K. 2014. Influence of Plant Growth Regulators on Growth, Flowering and Quality of Tomato (Lycopersicon esculentum Mill), cv. H-86. Indian Journal of Hill Farming 27(2):19-22
Wang H., Jones B., Li S.H., Frasse P.,Delalande C., Regad F., Chaabouni S., Latche A., Pech J., and Bouzayen M. 2005. The tomato Aux/IAA transcription factor IAA9 is involved in fruit development and leaf morphogenesis. The Plant Cell, 17: pp. 2676-2692.

Wang L.J., Chen S.J., Kong W.F., Li S.H., \& Archibold, D.D. 2006. Salicylic acid pretreatment alleviates chilling injury and affects the antioxidant system and heat shock proteins of peaches during cold storage. Postharvest. Biol. Technol., 41:244-25

Woodward A.W. and Bartel B. 2005. Auxin: regulation, action, and interaction. Annals of Botany, 95: pp. 707-735.

Younis M. E. and Tigani L. S. E. 1977. Comparative effects of growth substance on the growth, flowering and fruiting of tomato (Lycopersicon esculentum Mill.) plants. Acta Agronomica Academiae Scientiarumientiarum Hungaricae. 26: pp. 89-103.

Zhao Y. 2008. The role of local biosynthesis of auxin and cytokinin in plant development. Current Opinion in Plant Biology, 11:pp. 16-22.

\section{How to cite this article:}

Kartik Pramanik and Priyadarshani P. Mohapatra. 2017. Role of Auxin on Growth, Yield and Quality of Tomato - A Review. Int.J.Curr.Microbiol.App.Sci. 6(11): 1624-1636. doi: https://doi.org/10.20546/ijcmas.2017.611.195 